\title{
Intraocular pressure in subjects with beta-thalassemia minor
}

\author{
Pressão intraocular em indivíduos com talassemia beta minor \\ Șakir Özgür Keșkek', Nedime Șahinoğlu Keșkek², Gizem Ilgın', Emine Sukgen³ \\ 1. Department of Internal Medicine, Numune Training and Research Hospital, Adana, Turkey. \\ 2. Department of Ophthalmology, Bașkent University School of Medicine, Adana, Turkey. \\ 3. Department of Ophthalmology, Numune Training and Research Hospital, Adana, Turkey
}

\begin{abstract}
Purpose: Beta-thalassemia minor, a common hereditary blood disorder in Mediterranean countries such as Turkey, is associated with insulin resistance. Insulin resistance, in turn, can be associated with excessively high intraocular pressure and, therefore, intraocular pressure-induced blindness. This study aimed to investigate the intraocular pressure in subjects with beta-thalassemia minor. Methods: We conducted a cross-sectional study comprising of 203 subjects divided into two groups: beta-thalassemia minor (103) and healthy (100).Hemoglobin electrophoresis was performed and complete blood count, blood pressures, serum fasting glucose and insulin levels were measured. All subjects underwent ophthalmological examinations including intraocular pressure measurements. Results: Intraocular pressure in the subjects with beta-thalassemia minor was significantly lower than that in healthy subjects $(p=0.007)$. Additionally, intraocular pressure was inversely correlated with hemoglobin $\mathrm{A}_{2}$ levels $(p=0.001, r=-0.320)$. Serum insulin and systolic blood pressure were significantly higher in subjects with beta-thalassemia minor $(p=0.03, p=0.009$, respectively). Conclusion: Subjects with beta-thalassemia minor had lower intraocular pressure than healthy controls, suggesting beta-thalassemia minor may actually protect against high intraocular pressure.
\end{abstract}

Keywords: Beta-Thalassemia; Blood pressure; Glaucoma; Hemoglobin $\mathrm{A}_{2}$; Intraocular pressure

Submitted for publication: January 22, 2018

Accepted for publication: October 19, 2018

Funding: No specific financial support was available for this study.

Disclosure of potential conflicts of interest: None of the authors have any potential conflicts of interest to disclose.

Corresponding author: Șakir Özgür Keșkek.

Department of Internal Medicine. Numune Training and Research Hospital

Serin Evler Mahallesi - Ege Bağatur Bulvarı, Yüreğir - 01240 - Adana - Turkey

E-mail: drkeskek@yahoo.com

Approved by the following research ethics committee: Numune Training and Research Hospital (\# ÇUTF/13.01.2017/53).
RESUMO I Objetivo: Beta-talassemia menor é uma doença hereditária comum no sangue em países mediterrâneos como a Turquia e está associada à resistência à insulina. A resistência à insulina por sua vez, pode estar associada à pressão intraocular excessivamente alta e, portanto à cegueira induzida pela pressão intraocular. Este estudo teve como objetivo investigar a pressão intraocular em indivíduos com beta-talassemia menor. Métodos: Foi realizado um estudo transversal compreendendo 203 indivíduos divididos em 2 grupos: beta-talassemia menor (103) e saudável (100). Eletroforese de hemoglobina foi realizada e hemograma completo, pressão arterial, glicemia em jejum e níveis de insulina medidos. Todos os indivíduos foram submetidos foram submetidos a exames oftalmológicos, incluindo medidas de pressão intraocular. Resultados: A pressão intraocular nos indivíduos com beta-talassemia menor foi significativamente menor do que em indivíduos saudáveis $(p=0,007)$. Além disso, a pressão intraocular foi inversamente correlacionada com os níveis de hemoglobina $A_{2}(p=0,001, r=-0,320)$. Insulina sérica e pressão arterial sistólica foram significativamente maiores em indivíduos com beta-talassemia menor $(p=0,03, p=0,009$, respectivamente). Conclusão: Os indivíduos com beta-talassemia menor tiveram pressão intraocular menor do que os controles saudáveis, sugerindo que a beta-talassemia menor pode, na verdade, proteger contra a alta pressão intraocular.

Descritores: Talassemia beta; Pressão sanguínea; Glaucoma: Hemoglobina $A_{2}$; Pressão intraocular

\section{INTRODUCTION}

Beta-thalassemia syndromes are a group of hereditary blood disorders characterized by reduced or absent globin beta-chain synthesis, resulting in reduced hemoglobin in red blood cells (RBCs), decreased RBC production and anemia. Beta-thalassemia minor (BTM) is a term used to describe reduced or absent production of $\beta$-globin resulting from the inheritance of a single heterozygous gene. Patients with BTM are usually clinically asymptomatic but may have mild anemia identifiable 
only through blood examination. BTM is reported to be most prevalent in the Mediterranean region such as Turkey, Greece, and Italy ${ }^{(1-3)}$.

Intraocular pressure (IOP), the fluid pressure inside the eye, is mainly determined by the coupling of the production and drainage of aqueous humor via the trabecular meshwork located in the anterior chamber angle. Excessive IOP is the most strongest and only treatable risk factor for developing glaucoma ${ }^{(4,5)}$. Additionally, excessive IOP has also been reported to be associated with other conditions such as diabetes, hypertension, obesity and metabolic syndromes ${ }^{(6-9)}$. Metabolic syndromes and its components in turn, further exacerbate these conditions as it is strongly associated with insulin resistance, which plays a vital role in the development of diabetes, hypertension and obesity, and has been demonstrated in patients with $\mathrm{BTM}^{(12,13)}$. Hence, studies are required to investigate the various regulatory systems mediating IOP to understand the mechanisms underlying glaucoma. This study aimed to investigate whether insulin resistance in BTM leads to high IOP.

\section{METHODS}

A cross-sectional study was carried out in the internal medicine outpatient clinics of a tertiary hospital in Turkey from July 30, 2015 to November 30, 2016. The study was approved by the Institutional Review Board. Informed consent was obtained from all participants. All procedures followed the ethical standards of the responsible committee on human experimentation and the Helsinki Declaration.

Power analysis $(80 \%)$ was performed to determine the optimal sample size for the study. Subjects with a history of glaucoma, ocular inflammation such as uveitis, ocular surgery, use any drugs (steroids, beta-blockers, anti-depressants, bronchodilators, etc.), malignancy, and any other acute or chronic disease were excluded. Additinally, women who were breastfeeding or pregnant were also excluded. A total of 203 subjects at least 18 years of age were enrolled in this study. The participants were divided into two study group: 103 subjects with BTM and the control group 100 healthy subjects. The criteria for the diagnosis of BTM were: hemoglobin $\mathrm{A}_{2}$ $\left(\mathrm{HbA}_{2}\right) \geq 3.5 \%$, mean corpuscular volume $(\mathrm{MCV})<80 \mathrm{fl}$ and hemoglobin $F(\mathrm{HbF})=2 \%-10 \%$.

Venous blood samples were collected in the morning from each participant after overnight fasting. A complete blood count and hemoglobin electrophoresis was per- formed for all of the samples. Fluorescence flow cytometry (Sysmex XE 2100i, [manufacturer], Japan) was used for the complete blood counts, and high performance liquid chromatography (Primus Ultra 2, [manufacturer], USA) was used to analyze the electrophoretic data. Serum glucose and lipids were analyzed on a Synchron LX 20 (Beckman Coulter, Massachusetts, USA) using commercially available kits. Insulin levels were measured on an Architect 12000 SR (Abbott, Illinois, USA). Insulin resistance was measured using the homeostasis model assessment (HOMA-IR). Ferritin, vitamin B12 and folate levels were measured by electrochemiluminescence immunoassay (C-601, Roche, Japan). Trained nurses measured blood pressure using a sphygmomanometer three times per subject at one-minute intervals. Each subject was allowed a 10-min rest prior to measurement and was sitting at the time of measurement.

Ophthalmological examinations were performed between 8:00 am and 11:00 am, and included the best-corrected visual acuity, refraction, IOP measurement by Goldmann applanation tonometry and dilated fundus examination. Two ophthalmologists (NSK and ES) took three consecutive measurements for each eye, and the average IOP of the right eye was used for analysis.

MedCalc 16.8.4 (MedCalc Belgium) was used for statistical analysis. Categorical measurements are reported as number and percentage and were analyzed by Chi-square tests; quantitative measurements are reported as the mean \pm standard deviation and were analyzed for normality by Kolmogorov-Smirnov tests. For normally distributed data, t-tests or Mann- Whitney $\mathrm{U}$ tests were used for groupwise comparisons of quantitative measurements. Pearson correlation coefficients were derived to analyze the degree of association between two variables (including p-value and 95\% confidence interval for $r$ ). Log transformation was used for variables that were not normally distributed. Multiple linear regression tests (backward method) were used to analyze the relationship between the dependent variable $\left(\mathrm{HbA}_{2}\right)$ and one or more independent variables (predictor variables or explanatory variables). A p-value of less than 0.05 was considered to be statistically significant.

\section{RESULTS}

As seen in table 1, the experimental and control groups were comparable according to age (36.6 \pm 11.2 and $38.4 \pm 8.8$ years, respectively; $p=0.197$ ) and sex $(68.9 \%$ and $62 \%$ women, respectively; $p=0.635)$. 
$\mathrm{HbA}_{2}(\%)$ and $\mathrm{HbF}(\%)$ percentages of subjects with BTM were higher than those in healthy subjects. Mean $\mathrm{HbA}_{2}$ (study, $4.85 \pm 0.81 \%$; control, $3.81 \pm 1.03 \%$ ) and $\mathrm{HbF}$ (study, $2.06 \pm 0.35 \%$; control, $0.26 \pm 0.42 \%$ ) levels were significantly higher in subjects with BTM compared to controls. Mean MCV was significantly lower in subjects with BTM compared to controls $(65.3 \pm 4.1 \mathrm{fl}$ and $81.5 \pm 9.3 \mathrm{fl}$, respectively; $\mathrm{p}<0.001)$. Hemoglobin and hematocrit levels were significantly lower $(p<0.001)$, and RBC levels were significantly higher $(p<0.001)$ in subjects with BTM compared to the control group (Table 1). There were no statistically significant differences between groups in platelets, white blood cells (WBCs), ferritin, vitamin B12, and folate levels of the groups ( $p$ $>0.05$ in all cases). Mean central corneal thickness and refraction were comparable between groups $(p=0.371$, 0.466 , respectively; Table 1).

Fasting glucose, insulin, and HOMA-IR levels were significantly higher in the study group than the control group $(p=0.027, p=0.03, p=0.02$, respectively; Table 2). Systolic blood pressure in the BTM group was significantly lower than that in the control group $(110.7 \pm$ $11.4 \mathrm{mmHg}$ vs. $115.1 \pm 12.5 \mathrm{mmHg} ; \mathrm{p}=0.009$ ), whereas diastolic blood pressure was similar between groups

Table 1. Biochemical parameters and demographics of the study and control groups

\begin{tabular}{|c|c|c|c|}
\hline & $\begin{array}{l}\text { BTM group } \\
(\mathrm{N}=103)\end{array}$ & $\begin{array}{l}\text { Control group } \\
(N=100)\end{array}$ & p-value \\
\hline Age (years) & $36.6 \pm 11.20$ & $38.40 \pm$ & 0.197 \\
\hline Female N (\%) & $71(68.9)$ & $62(62)$ & 0.635 \\
\hline $\mathrm{HbA}_{2}(\%)$ & $4.85 \pm 0.81$ & $2.06 \pm 0.35$ & $<0.001$ \\
\hline HbF (\%) & $3.81 \pm 001.03$ & $0.26 \pm \quad 0.42$ & $<0.001$ \\
\hline $\mathrm{MCV}(\mathrm{fL})$ & $65.30 \pm 004.10$ & $84.80 \pm$ & $<0.001$ \\
\hline $\operatorname{RBC}\left(10^{12} / \mathrm{L}\right)$ & $5.32 \pm \quad 0.77$ & $4.77 \pm \quad 0.57$ & $<0.001$ \\
\hline Hemoglobin (g/dL) & $11.60 \pm 1.80$ & $12.90 \pm$ & $<0.001$ \\
\hline Hematocrit (\%) & $36.60 \pm$ & $39.20 \pm$ & 0.001 \\
\hline WBC $\left(10^{9} / \mathrm{L}\right)$ & $7.60 \pm 1.90$ & $7.50 \pm$ & 0.758 \\
\hline PLT $\left(10^{3} / \mu \mathrm{L}\right)$ & $273.90 \pm 89.60$ & $295.30 \pm 82.20$ & 0.069 \\
\hline Vitamin B12 (pg/mL) & $310.50 \pm 124.00$ & $329.30 \pm 125.80$ & 0.084 \\
\hline Folate $(\mathrm{ng} / \mathrm{mL})$ & $8.60 \pm \quad 3.40$ & $8.50 \pm 003.10$ & 0.784 \\
\hline Ferritin $(\mathrm{ng} / \mathrm{mL})$ & $50.40 \pm 31.30$ & $47.00 \pm 38.20$ & 0.154 \\
\hline $\mathrm{CCT}(\mu \mathbf{m})$ & $536.50 \pm 28.80$ & $540.30 \pm 31.60$ & 0.371 \\
\hline Refraction (diopter) & $\begin{array}{c}-1.20 \pm 3.13 \text { (range } \\
+6.00 \text { to }-12.5)\end{array}$ & $\begin{array}{c}-1.50 \pm 2.70 \text { (range } \\
+5.00 \text { to }-11.00 \text { ) }\end{array}$ & 0.466 \\
\hline
\end{tabular}

$\mathrm{BTM}=$ beta-thalassemia minor; $\mathrm{CCT}=$ central corneal thickness; $\mathrm{HbA}_{2=}$ Hemoglobin $\mathrm{A}_{2} ; \mathrm{HbF}=$ hemoglobin $\mathrm{F} ; \mathrm{MCV}=$ mean corpuscular volume; $\mathrm{PLT}=$ platelet; $\mathrm{RBC}=$ red blood cell; $\mathrm{WBC}=$ white blood cell.
( $p=0.708)$. Triglyceride, LDL, and HDL levels were comparable between groups $(p=0.222, p=0.569, p=0.059$, respectively; Table 2).

Mean IOP was significantly lower in the BTM group relative to that in the control group $(12.4 \pm 2.1 \mathrm{mmHg}$ and $13.2 \pm 2.3 \mathrm{mmHg}$, respectively; $\mathrm{p}=0.007$; Figure 1 ); IOP in the study group was inversely correlated with $\mathrm{HbA}_{2}(\mathrm{p}=0.001, \mathrm{r}=-0.320$; Figure 2$)$ and positively correlated with systolic blood pressure $(p=0.001, r=0.308$; Figure 3). Multiple regression analyses using IOP as the dependent variable and $\mathrm{HbA}_{2}$ and systolic blood pressure as independent variables demonstrated a significant correlation between IOP and $\mathrm{HbA}_{2}(\mathrm{p}=0.003)$, as well as systolic blood pressure $(p=0.01$; Table 3$)$.

Table 2. Metabolic parameters, blood pressure and intraocular pressure of the subject groups

\begin{tabular}{lrrr}
\hline & $\begin{array}{c}\text { BTM Group } \\
(\mathbf{N = 1 0 3 )}\end{array}$ & $\begin{array}{c}\text { Control group } \\
\mathbf{( N = 1 0 0 )}\end{array}$ & P-value \\
\hline Fasting glucose $(\mathrm{mg} / \mathrm{dL})$ & $94.40 \pm 10.40$ & $91.2 \pm 9.4$ & $\mathbf{0 . 0 2 7}$ \\
\hline Fasting insulin $(\mu \mathrm{U} / \mathrm{mL})$ & $12.60 \pm 8.40$ & $10.7 \pm 6.6$ & 0.030 \\
\hline HOMA-IR & $2.86 \pm 1.98$ & $2.4 \pm 1.6$ & 0.020 \\
\hline Systolic blood pressure (mmHg) & $110.70 \pm 11.40$ & $115.1 \pm 12.5$ & 0.009 \\
\hline Diastolic blood pressure (mmHg) & $70.40 \pm 9.30$ & $71.0 \pm 11.3$ & 0.708 \\
\hline HDL (mg/dL) & $47.30 \pm 12.00$ & $49.4 \pm 10.3$ & 0.059 \\
\hline LDL (mg/dL) & $104.50 \pm 41.60$ & $105.5 \pm 35.2$ & 0.569 \\
\hline Triglyceride (mg/dL) & $133.30 \pm 44.60$ & $127.3 \pm 49.6$ & 0.222 \\
\hline Intraocular pressure (mmHg) & $12.40 \pm 2.10$ & $13.2 \pm 2.3$ & 0.007 \\
\hline
\end{tabular}

$\mathrm{BTM}=$ beta-thalassemia minor $\mathrm{HDL}=$ high density lipoprotein; $\mathrm{HOMA}-\mathrm{IR}=$ homeostasis model assessment of insulin resistance; $\mathrm{LDL}=$ low density protein.

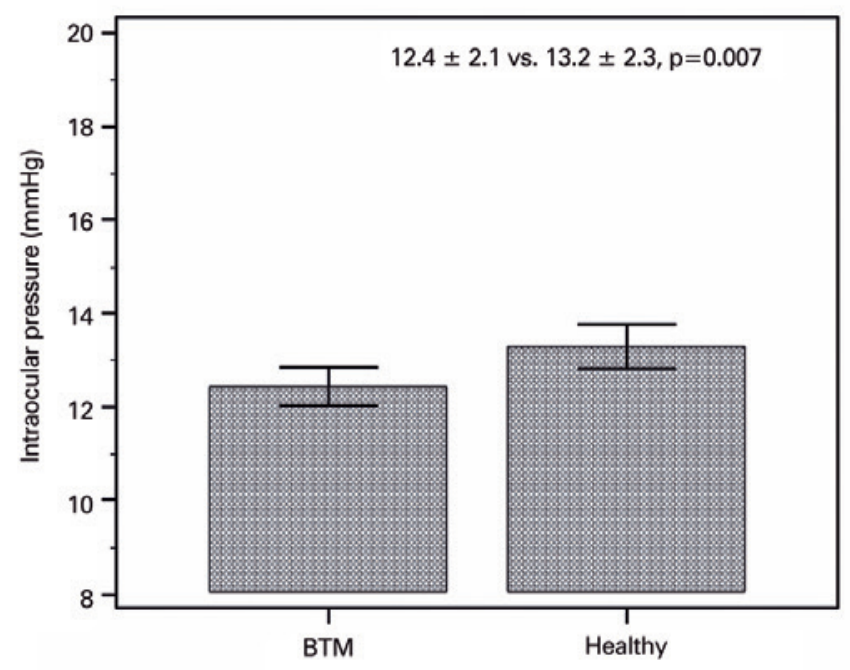

BTM $=$ Beta-thalassemia minor.

Figure 1. The mean intraocular pressures of the BTM and healthy control groups. 


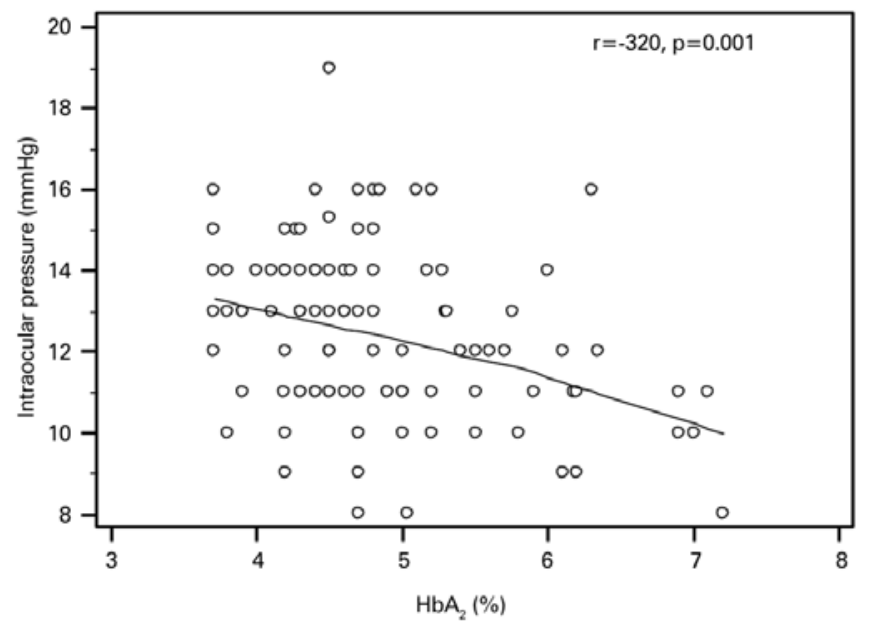

Figure 2. Scatter diagram of the correlation between intraocular pressure and hemoglobin $\mathrm{A}_{2}\left(\mathrm{HbA}_{2}\right)$ in subjects with beta-thalassemia minor

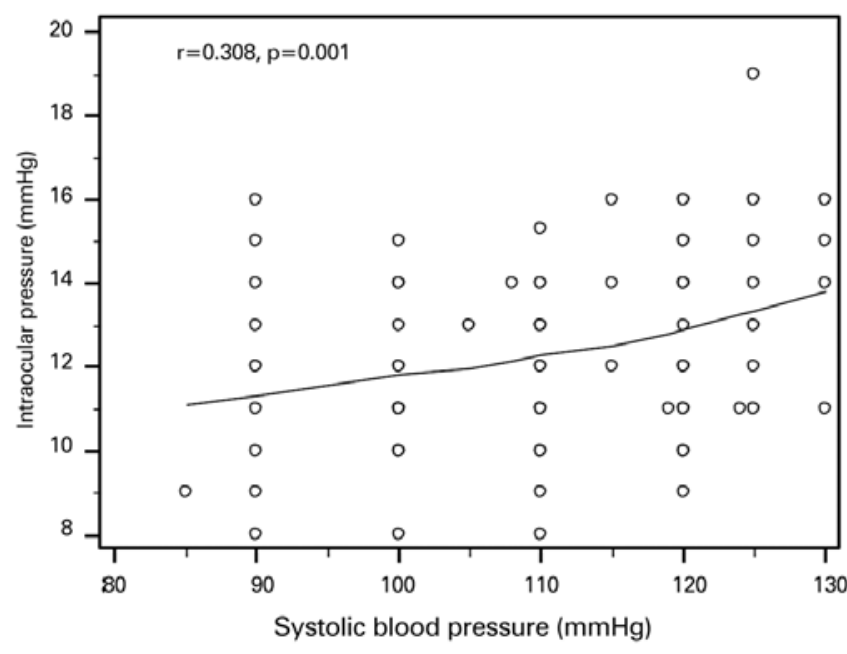

Figure 3. Scatter diagram of the correlation between intraocular pressure and systolic blood pressure in subjects with beta-thalassemia minor

Table 3. Statistically significant multiple linear regression analyses*

\begin{tabular}{lccccc}
\hline $\begin{array}{l}\text { Independent } \\
\text { variables }\end{array}$ & Coefficient & Std. error & $\mathbf{r}_{\text {partial }}$ & $\mathbf{t}$ & P-value \\
\hline $\begin{array}{l}\text { (Constant) } \\
\mathrm{HbA}_{2}\end{array}$ & $-0.71,1101$ & & & & \\
$\begin{array}{l}\text { Systolic blood } \\
\text { pressure }\end{array}$ & 0.04433 & 0.01716 & 0.2537 & 2.583 & 0.0113 \\
\hline
\end{tabular}

* = All analyses utilized the backward method.

Intraocular pressure was the dependent variable; independent variables included. $\mathrm{HbA}_{2}=$ Hemoglobin $\mathrm{A}_{2}$; Std. error= standard error.

\section{DISCUSSION}

Our results revealed low IOP in subjects with BTM when compared with healthy subjects. Additionally, we found an inverse correlation between IOP and $\mathrm{HbA}_{2}$ and a positive correlation between IOP and systolic blood pressure. Moreover, we also found low systolic blood pressure, but high levels of glucose, insulin, and HOMA-IR, in subjects with BTM.

BTM is associated with various metabolic disturbances $^{(12-14)}$, including insulin resistance ${ }^{(12,13)}$. Research suggests that chronic microcytic erythrocytic hemolysis in BTM patients leads to oxidative stress and liver inflammation, which then lead to insulin resistance ${ }^{(12,14)}$. Gozashti et al. noted BTM is associated with high prevalence of carbohydrate-related metabolic disorders which result liver inflammation and subsequent insulin resistance ${ }^{(15)}$. On the other hand, Gozashti and colleagues ATP-related data indicated that the prevalence of metabolic syndrome in thalassemia patients was below that of the normal population ( $16.7 \%$ vs $36.7 \%$ ).

Here we identified low systolic blood pressure in subjects with BTM. This is in agreement with other studies that reported low blood pressure in subjects with $\mathrm{BTM}^{(13)}$. Hemodynamic variations were seen in anemia such as arterial dilation and decreased blood viscosity may lead to low blood pressure in subjects with $\mathrm{BTM}^{(16)}$. Indeed, Vyssoulis et al. reported that hypertensive patients with BTM have better 24-hour blood pressure profiles compared to patients without $\mathrm{BTM}^{(17)}$.

IOP in subjects with BTM was low relative to controls, and was positively correlated with systolic blood pressure. High blood pressure is an important risk factor for $\mathrm{IOP}^{(6,9)}$ hypertension causes excessive production of aqueous humor, increased episcleral venous and ciliary arterial pressures, and increased sympathetic activity leading to high $\mathrm{IOP}^{(18,19)}$. In a Taiwanese population, Lin et al., reported that of all the variables they measured, blood pressure was the strongest predictor of elevated IOP; this finding is supported by a recent epidemiologic study, as well as the correlation between IOP and systolic blood pressure described herein ${ }^{(20-21)}$. Thus, the lower systolic pressure may be a protective factor for glaucoma in patients with BTM.

In this study, we found high levels of RBCs and low levels of hemoglobin in subjects with BTM. BTM leads to microcytic anemia and an associated increase in RBCs that is only minimally impacted by the lower $\mathrm{Hb}$ concentration $^{(22)}$. 
Our study has some limitations. First, the cross-sectional design of this study limited its ability to establish causality. Intraocular pressure does increase gradually with age, and the subjects included here were relatively young, so longitudinal studies may be more effective regarding the potential associations with glaucoma. Second, 24-hour ambulatory blood pressure monitoring was not performed. Third, genetic analyses to confirm (or define) BTM in the study group would have been beneficial. Lastly, a multicenter study with a larger sample size could be more demonstrative. The study design was also strong in its sample size, which was large enough for power analyses, and in its similarity in age and sex between groups (both characteristics can influence IOP).

The study concludes that low IOP could hypothetically afford some protection against glaucoma or other disorders involving high IOP.

\section{REFERENCES}

1. Damon EL, Andreadis C. Disorders of Hemoglobin. In: Papadakis MA, McPhee SJ, editors. Current medical diagnosis and treatment. $53^{\text {rd }}$ ed. New York: McGraw-Hill; 2014. p. 477-80.

2. Benz EJ. Disorders of Hemoglobin. In: Kasper DL, Fauci AS, Hauser SL, Longo DL, Jameson JL, Loscalzo J., editors. Harrison's principles of internal medicine. 19th ed. New York: McGraw-Hill; 2015. p. 637-9.

3. Galanello R, Origa R. Beta-thalassemia. Orphanet J Rare Dis. 2010; 5(1):11.

4. Quigley HA. Number of people with glaucoma worldwide. $\mathrm{Br}$ J Ophthalmol. 1996;80(5):389-93.

5. Wong TY, Loon SC, Saw SM. The epidemiology of age related eye diseases in Asia. Br J Ophthalmol. 2006;90(4):506-11.

6. Chung HJ, Hwang HB, Lee NY. The association between primary open-angle glaucoma and blood pressure: two aspects of hypertension and hypotension. BioMed Res Int. 2015;2015:827516.

7. Zhao D, Cho J, Kim MH, Friedman DS, Guallar E. Diabetes, fasting glucose, and the risk of glaucoma: a meta-analysis. Ophthalmology. 2015;122(1):72-8

8. Mori K, Ando F, Nomura H, Sato Y, Shimokata H. Relationship between intraocular pressure and obesity in Japan. Int J Epidemiol. 2000;29(4):661-6.
9. Sahinoglu-Keskek N, Keskek SÖ, Cevher S, Kirim S, Kayiklik A, Ortoglu G, et al. Metabolic syndrome as a risk factor for elevated intraocular pressure. Pak J Med Sci. 2014;30(3):477-82.

10. Kim HA, Han K, Lee YA, Choi JA, Park YM. Differential Association of Metabolic Risk Factors with Open Angle Glaucoma according to Obesity in a Korean Population. Sci Rep. 2016;6(1):38283.

11. Son J, Koh H, Son J. The association between intraocular pressure and different combination of metabolic syndrome components. BMC Ophthalmol. 2016;16(1):76.

12. Bahar A, Kashi Z, Sohrab M, Kosaryan M, Janbabai G. Relationship between beta-globin gene carrier state and insulin resistance. J Diabetes Metab Disord. 2012;19;11:22.

13. Kırım S, Keşkek ŞÖ, Turhan A, Saler T. Is $\beta$-thalassaemia minor associated with metabolic disorder? Med Princ Pract. 2014;23(5): 421-5.

14. Tong PC, Ng MC, Ho CS, So WY, Li JK, Lam CW, et al. C-reactive protein and insulin resistance in subjects with thalassemia minor and a family history of diabetes. Diabetes Care. 2002;25(8):1480-1.

15. Gozashti MH, Hasanzadeh A, Mashrouteh M. Prevalence of metabolic syndrome in patients with minor beta thalassemia and its related factors: a cross-sectional study. J Diabetes Metab Disord. 2014;13(1):108.

16. Karimi M, Marvasti VE, Motazedian S, Sharifian M. Is beta-thalassemia trait a protective factor against hypertension in young adults? Ann Hematol. 2006;85(1):29-31.

17. Vyssoulis G, Karpanou E, Kyvelou SM, Tzamou V, Triantafyllou A, Theodosiadis G, et al. Ambulatory blood pressure profile in hypertensive patients with $\beta$-thalassemia minor. Hypertens Res. 2011;34(2):253-6. Erratum in Hypertens Res. 2012;35(6):674. Triantafyllou, Andreas [corrected to Triantafyllou, Athanasios].

18. Bulpitt C), Hodes $\mathrm{C}$, Everitt MG. Intraocular pressure and systemic blood pressure in the elderly. Br J Ophthalmol. 1975;59(12):717-20.

19. Carel RS, Korczyn AD, Rock M, Goya l. Association between ocular pressure and certain health parameters. Ophthalmology. 1984; 91(4):311-4.

20. Lin CP, Lin YS, Wu SC, Ko YS. Age- and gender-specific association between intraocular pressure and metabolic variables in a Taiwanese population. Eur J Intern Med. 2012;23(1):76-82.

21. Khawaja AP, Springelkamp H, Creuzot-Garcher C, Delcourt C, Hofman A, Höhn R, et al.; European Eye Epidemiology ( $\left.E^{3}\right)$ Consortium. Associations with intraocular pressure across Europe: The European Eye Epidemiology (E3) Consortium. Eur J Epidemiol. 2016;31(11):1101-11.

22. Clarke GM, Higgins TN. Laboratory investigation of hemoglobinopathies and thalassemias: review and update. Clin Chem. 2000; 46(8 Pt 2):1284-90. 